\title{
HABILITACE JULIA SUCHÉHO Z TEORETICKÉ FYZIKY NA ČESKÉ TECHNICE V PRAZE
}

\author{
EMILIE TĚŠÍNSKÁ
}

\section{JULIUS SUCHÝ'S HABILITATION IN THEORETICAL PHYSICS AT THE CZECH TECHNICAL UNIVERSITY IN PRAGUE}

This article was inspired by a reedition of two documents prepared for this number of HUCP by Jana Ratajová, which concern the professional career of the Czech physicist Julius Suchý (1879-1920). The aim of this contribution was to outline the broader context of Suchý's stay with Hendrik A. Lorentz at the Leiden University in 1908-1909 and his subsequent habilitation in theoretical physics at the Czech Technical University in Prague in 1913. The circumstances of finishing his habilitation are illustrated by Suchýs letters to Hendrik A. Lorentz, written in 1909-1911, whose transcription (from the German original) is included as this article's supplement.

Keywords: Julius Suchý (1879-1920) - Hendrik A. Lorentz - Albert Einstein - physics at Prague universities

DOI: $10.14712 / 23365730.2019 .15$

Ve vazbě na edici dvou nově objevených, zajímavých historických dokumentů, kterou připravila Jana Ratajová, se tento článek věnuje širším okolnostem studijního pobytu Julia Suchého u H. A. Lorentze v Leidenu, jeho publikaci o tepelném záření a vedení tepla a habilitaci z teoretické fyziky na české vysoké škole technické v Praze. Článek se opírá o písemné prameny, které se $\mathrm{k}$ tématu podařilo nalézt $\mathrm{v}$ archivech. Jako prŕloha je připojen přepis několika dopisů J. Suchého H. A. Lorentzovi z let 1909-1911, které se dochovaly v písemné pozůstalosti H. A. Lorentze v archivu Noord-Hollands Archief v Haarlemu, v Nizozemí. ${ }^{1}$

Dílčí biografické údaje ostatních osobností, jež jsou v článku zmiňovány v kontextu se sledovaným tématem, vycházejí z personálních spisů uchovaných v archivech př́islušných vysokých škol (v prvé řadě v Archivu Univerzity Karlovy a Archivu ČVUT v Praze), ze spisů rakouského ministerstva kultu a vyučování a československého ministerstva školství a národní osvěty (uložených v Národním archivu v Praze), popř. z biografických článků, publikovaných v dobovém odborném tisku. Většinou se jedná o data dobře známá a nesporná, která uvádíme bez odkazu na konkrétní historický pramen.

1 Noord-Hollands Archief (Haarlem, The Netherlands), dále NHA (Haarlem, NL) f. Papers of prof. H. A. Lorentz (1853-1928) 1866-1930, i. č. 77 (J. Suchý). 


\section{Práce Julia Suchého o tepelném záření a vedení tepla}

Počátkem listopadu 1911 podal 32letý profesor české vyšší reálky v Praze na Malé Straně PhDr. Julius Suchý žádost o habilitaci pro obor teoretické fyziky na české vysoké škole technické (dále zkráceně česká technika) v Praze. ${ }^{2}$ Jako habilitační spis předložil práci „Wärmestrahlung und Wärmeleitung“, která byla krátce předtím uveřejněna v renomovaném zahraničním fyzikálním časopise Annalen der Physik. ${ }^{3}$

Práce vzešla ze studijního pobytu J. Suchého na univerzitě v Leidenu v Holandsku v letech 1908-1909, kde pracoval u H. A. Lorentze, jednoho z předních fyziků té doby. ${ }^{4}$ Suchý práci dokončil až po návratu do Prahy, s odstupem dvou let a s konečnou odbornou redakcí H. A. Lorentze, který také zaslal práci k publikaci do Annalen der Physik. ${ }^{5}$

Dokončení práce po návratu do vlasti J. Suchému znesnadňovalo pracovní vytížení na střední škole, rodinné starosti a při obtížnosti tématu hlavně odtrženost od tvůrčí atmosféry leidenské fyziky. ${ }^{6}$

Problém nastolený a řešený $\mathrm{v}$ práci, tj. podíl tepelného záření na celkové tepelné vodivosti látek, vycházel z prací H. A. Lorentze, z teorie záření a elektronové teorie; šlo o teoreticky zajímavou úvahu, ovšem obtížně experimentálně ověřitelnou. $Z$ toho vyplynuly některé pochybnosti při posuzování práce $\mathrm{v}$ habilitačním ř́zení J. Suchého na pražské české technice. Posudek na práci, o který J. Suchý požádal Alberta Einsteina a jehož text v původním znění a českém překladu přináší edice J. Ratajové, sehrál pro pochopení významu práce a udělení habilitace J. Suchému důležitou roli.

2 Dokumenty připojené $\mathrm{k}$ žádosti (životopis a seznam přednášek, které žadatel hodlá v případě udělení habilitace konat) byly datovány „Smíchov 9. listopadu 1911“. Národní archiv, Praha (dále NA), fond Ministerstvo kultu a vyučování - rakouské (dále MKV-R), kart. 257, i. č. 87, sign. 7, Professoren Prag, Suchý Julius, spis č. $38.279 / 1913$.

3 Julius SuchÝ, Wärmestrahlung und Wärmeleitung, Annalen der Physik, Vierter Folge, Bd. 36, Leipzig 1911, S. 341-382. Datace v závěru uvádí: „Eingegangen 2. August 1911“.

4 Hendrik A. LoRENTz (1853-1928), holandský fyzik, 1877-1912 působil jako profesor teoretické fyziky na univerzitě v Leidenu. Koncem roku 1909 byl s účinností od 8. ledna 1910 jmenován kurátorem fyzikálního kabinetu (muzea) Teylerovy nadace v Haarlemu, kam přesídlil z Leidenu koncem července 1912. S univerzitou v Leidenu zůstal spojen jako externí profesor. Svými pracemi H. A. Lorentz zásadně přispěl v řadě oblastí fyziky, zejména elektromagnetismu, teorie relativity a elektronové teorie. V roce 1902 byla H. A. Lorentzovi společně s P. Zeemanem udělena Nobelova cena za teoretické objasnění tzv. Zeemanova jevu. Od roku 1881 byl členem Královské nizozemské akademie věd a umění. V roce 1911 předsedal prvnímu Solvayskému kongresu, který byl věnován otázkám záření. V roce 1923 byl zvolen čestným členem také Jednoty československých matematiků a fyziků (stejně jako další z velkých leidenských fyziků, ředitel laboratoře nízkých teplot na univerzitě v Leidenu Heike Kammerlingh Onnes). Dodejme, že H. A. Lorentz nabídl profesuru teoretické fyziky na leidenské univerzitě, která se měla uvolnit jeho odchodem do Haarlemu, A. Einsteinovi. Ten však odmítl, nebot' se již rozhodl pro post na technice v Curychu. Lorentzovým nástupcem se poté stal Paul Ehrenfest, který se před tím ucházel mj. o profesuru po A. Einsteinovi na pražské německé univerzitě.

5 Dopisem z 29. července 1911 H. A. Lorentz informoval Wilhelma Wiena (který byl spolu s Maxem Planckem vydavatelem Annalen der Physik), že zasílá do Annalen der Physik pojednání Dr. J. Suchého o podílu tepelného záření na vedení tepla. Dodal, že práce byla vykonána během pobytu autora v Leidenu „und erhält, obgleich er das Thema keineswegs erschöpft hat, einige interessante Betrachtungen, so dass es mir sehr lieb wäre, wenn Sie die Abhandlung in der Annalen aufnehmen könnten. Die Richtigkeit der mathematischen Entwicklungen kann ich verbürgen."A. J. Kox (ed.), The Scientific Correspondence of H. A. Lorentz, Volume I, New York 2008, s. 337, dopis č. 224.

6 Vedle výuky fyziky ve třídách s velkým počtem žáků musel J. Suchý na žádost ředitele školy napsat příspěvek do výroční zprávy školy za rok 1910. Srov. J. SuchÝ, Některé nové př́stroje fysikální, in: Výroční zpráva c. k. státní české reálky na Malé Straně v Praze za školní rok 1909-10, Praha 1910, 15 s. Obsah tohoto článku resumoval J. Suchý německy v dopise H. A. Lorentzovi ze 17. záŕí 1910. 


\section{Počátek profesní kariéry Julia Suchého}

Julius Suchý se narodil 15. listopadu 1879 v Kroměříži, kde také v roce 1897 maturoval na českém vyšším gymnáziu; jeho otec Julius Suchý působil v Kroměřiži jako městský lékař. Univerzitní studia začal zřejmě na univerzitě ve Vídni, pokračoval v nich a dokončil je na české univerzitě v Praze (13. 12. 1901 složil zkoušku učitelské způsobilosti k výuce matematiky a fyziky v českém jazyce ve vyšších trrídách středních škol, 19. 7. 1902 byl promován doktorem filozofie). Profesní kariéru zahájil jako asistent při stolici pro vyšší matematiku a fyziku (přednosta Josef Theurer) na Báňské akademii v Př́ibrami v listopadu 1899. Od záấí 1903 souběžně působil jako suplující učitel na vyšším reálném gymnáziu v Př́ibrami. Koncem školního roku 1904/1905 vysokou školu opustil a od zář́i 1905 nastoupil jako středoškolský profesor na vyšší českou reálku v Praze na Malé Straně. ${ }^{7}$ Vědeckých ambicí se však nevzdal.

Již v roce 1903, po získání doktorátu filozofie, žádal J. Suchý rakouské ministerstvo kultu a vyučování o cestovní podporu „k návštěvě nějaké říšskoněmecké univerzity s cílem dalšího vzdělávání speciálním studiem v oboru fyziky“. Profesorské kolegium filozofické fakulty pražské české univerzity žádost podpořilo a navrhlo udělení cestovního stipendia ve výši $600 \mathrm{~K}$. Žádosti však nebylo vyhověno pro vyčerpání finančních prostředků pro př́slušný rok; také nebylo jasné, zda se žadatel hodlá habilitovat. ${ }^{8} \mathrm{~V}$ opakované žádosti v roce 1906 Suchý uvedl, že se hodlá habilitovat na pražské české univerzitě. Ze strany profesorského kolegia filozofické fakulty byla žádost opět podpořena, ale s dovětkem, že vyhovění žádosti nemá být prejudikováno Suchého habilitací, nebot' dosud nepředložil žádné samostatné práce, které by opravňovaly naději, že pronikl do vědy natolik, aby se mohl na nějaké univerzitě habilitovat. ${ }^{9}$ Cestovní stipendium ve výši $800 \mathrm{~K}$ a půlroční dovolenou na střední škole J. Suchý získal po opakování žádosti až na letní semestr $1908 .{ }^{10} \mathrm{Na}$ jaře toho roku pak odjel do Leidenu k H. A. Loretzovi. Odtud po několika měsících požádal o cestovní stipendium ještě na školní rok 1908/1909 a o prodloužení dovolené za účelem „,dalších studií v oboru fysiky na universitách zahraničních"s dovětkem: „Podepsaný koná tato studia, maje v úmyslu ucházeti se později o habilitaci pro obor fysiky na c. k. české universitě.“" $\mathrm{K}$ žádosti o cestovní stipendium, adresované ministerstvu kultu a vyučování a datované 19. května 1908, připojil (jako př́lohu pod písmenem g) „vyjádření prof. H. A. Lorentze“ (dokument viz edice J. Ratajové) a dodal: „Jak z př́lohy g) vysvitá, pracuje týž [žadatel J. Suchý] pod vedením prof. H. A. Lorentze na universitě v Leidenu v Nizozemí, a začal zde též samostatnou védeckou práci v oboru elektronové theorie. By podepsanému bylo možno práci tu se zdarem provésti, jakož i by témuž bylo možno pracovati také v laboratoři

7 Odchod J. Suchého z Př́ibrami časově spadá do doby přeměny tamní Báňské akademie na Vysokou školu báňskou, jejímž prvním rektorem byl jmenován profesor J. Theurer. Suchého nástupcem na stolici matematiky a fyziky se stal o dva roky mladší Václav Šebesta.

8 NA, f. MKV-R, kart. 931, i. č. 407, sign. 26 G 3, spis č. 8451/1903.

9 Tamtéž, spis č. 50149/1906 (souhrn na spise). Do roku 1908 uveřejnil J. Suchý jen několik drobných článků o fyzikálních principech a prrístrojích a v roce 1906 rozsáhlejší článek o Ernstu Machovi, vycházející ze dvou přednášek, které Suchý vykonal ve Filosofické jednotě 31. ledna a 24. února 1906. Srov. J. SuchÝ, Arnošt Mach, Česká mys1 7, 1906, s. 267-275, 333-347, 401-412.

10 Tamtéž, spisy č. 48110/1907, 37361/1907, 6997/1908. Studijní podpora 800 K za účelem dalšího vzdělávání v oboru fyziky byla J. Suchému povolena výnosem ministerstva kultu a vyučování z 25. února 1908. V době, kdy již působil jako středoškolských profesor, byly jeho žádosti o cestovní stipendium vázány na souhlas Zemské školní rady s udělením dovolené na střední škole. 
prof. Kamerlingha Onnesa na universitě v Leidenu, žádá podepsaný o udělení cestovního stipendia na př́ští školní rok a podává zároveň cestou přislušnou žádost o prodloužení dovolené.“ Žádost zakončil slovy: „Vzhledem k tomu, že doba jednoho semestru jest ku vědeckým pracím př́liš krátká, oddává se podepsaný naději, že vysoké c. $k$. ministerstvo dalším udělením stipendia umožní mu, by studia svá v zamýšleném rozsahu mohl vykonati a zakončiti; podepsaný se vynasnaži, by př́ležitosti jemu poskytnuté využil co nejlépe."11 Profesorské kolegium filozofické fakulty Suchého žádost, kterou zde předložil profesor experimentální fyziky Čeněk Strouhal, opět (a to jednomyslně) podpořilo k př́iznivému vyřízení, ovšem znova s dovětkem, že udělení podpory nemá být prejudikováno otázkou eventuální habilitace žadatele. ${ }^{12}$

\section{Dokončení práce o tepelném záření a vedení tepla}

Skutečnost, že se J. Suchý v roce 1909 vrátil ze studijního pobytu bez publikace, pochyby o oprávněnosti jeho vědeckých ambicí v akademických kruzích na filozofické fakultě pražské české univerzity posílila a Suchého šance na habilitaci na univerzitě ještě více zpochybnila. Předběhli ho jiní uchazeči, bezprostředně Václav Posejpal. ${ }^{13}$

Postavení a těžkosti, na které J. Suchý narážel po návratu ze studijního pobytu, zaznívají (v jeho interpretaci) v dopisech H. A. Lorentzovi z let 1909-1911. ${ }^{14}$ Vyplývá z nich, že mezi fyziky pražské české univerzity nenalezl J. Suchý velké porozumění a podporu při úsilí dokončit započatou práci. Zjevně nejbližší tématu Suchého práce byl profesor matematické (teoretické) fyziky František Koláček, který se zabýval aplikacemi Maxwellových rovnic v oboru optiky. Na profesora Koláčka odkazoval Suchého i H. A. Lorentz. Zdá se však, že Koláček zaujal k Suchého práci (a údajně i k elektronové teorii) pochybovačný, ne-li př́mo odmítavý postoj. ${ }^{15}$

Suchému bylo zřejmě z více stran doporučeno, aby raději urychleně dokončil prakticky zaměřenou experimentální práci o závislosti elektrického odporu železných a ocelových drátů na mechanickém napětí, kterou započal ještě před odjezdem na studijní pobyt měřeními v „modelárně“ c. k. horního závodu v Březových Horách u Př́brami z podnětu horního rady Diviše. Tuto práci předložil J. Suchý k publikaci v Rozpravách II.

11 Archiv Univerzity Karlovy (dále AUK), f. Akademický senát, kart. 166, fasc. Filosofická fakulta, 1907-08, č. 2575 (rukopisná žádost J. Suchého adresovaná ministerstvu kultu a vyučování, datováno Leiden 19. května 1908, viz obr. 2).

12 Tamtéž, přípis k ministerstvu kultu a vyučování z 20. 6. 1908 podepsaný děkanem Niederlem. Srov. též NA, MKV-R, kart. 931, i. č. 407, spis č. 30213/1908.

13 Václav Posejpal (1874-1935), rovněž středoškolský profesor, byl v letech 1908-09 na studijním pobytu na Collège de France v Paříži, kde pod vedením Henri Pellata dokončil práci o vlivu magnetického pole na Voltův jev. Práci započal v Praze, s využitím laboratoře a přístrojů profesora Václava Felixe na pražské české technice. Na základě dokončené práce se Posejpal v roce 1910 na pražské české univerzitě habilitoval z experimentální fyziky (habilitace byla potvrzena ministerstvem kultu a vyučování 24. 4. 1910). Srov. Václav PosejPal, O pravděpodobném účinku magnetického pole na Voltův effekt, Rozpravy II. třídy České akademie věd a umění (ČAVU) 17, 1908, č. 14, 8 s.; Týž, Sur l'influence du champ magnétique sur les différences de potentiel de Volta et sur les forces electromotorices de aimantation, Annales de chimie et de physique, sér. 8, 1909 , s. 478-501.

14 NHA (Haarlem, NL), citovaný fond. Přepis dopisů viz př́loha.

15 Tamtéž, dopis J. Suchého H. A. Lorentzovi ze 4. 12. 1909. 
(matematicko-přirodovédné) třidy České akademie věd a umění 30. dubna 1909. Vyšla v následujícím roce. ${ }^{16} \mathrm{~K}$ publikaci ji doporučil, v souhlase s F. Koláčkem a s řadou kritických výtek, profesor experimentální fyziky na pražské české univerzitě Bohumil Kučera. ${ }^{17}$ Také v závěru této práce Suchý děkuje za cenné rady H. A. Lorentzovi.

Mezi fyziky na pražské české univerzitě nalezl J. Suchý radu a podporu zřejmě jen u profesora experimentální fyziky Čeňka Strouhala (s nímž ho možná sblížila právě práce o ocelových a železných drátech). Strouhal Suchému údajně navrhoval, aby práci o tepelném záření a vedení tepla, s jejímž dokončením se Suchý potýkal, předložil k publikaci nejprve vídeňské akademii věd - zřejmě ve víře, že tam bude mít práce větší šanci na uveřejnění než v Annalen der Physik. ${ }^{18}$

Práci o podílu tepelného záření na vedení tepla dokončil J. Suchý zjevně s pomocí H. A. Lorentze na dálku; původní rukopis přepracoval, zkrátil a upravil dle Lorentzových připomínek. ${ }^{19}$

Po uveřejnění v Annalen der Physik v druhé polovině roku 1911 byla Suchého práce anotována $\mathrm{v}$ zahraničních referativních časopisech a zmíněna také v českých referátech o pokrocích fyziky v roce $1911 .{ }^{20}$ Autorem anotace v časopise Fortschritte der Physik byl dokonce Max von Laue. Ten shrnul obsah práce slovy: „Ausgehend von einem Reziprozitätssatz für die gegenseitige Zustrahlung zweier Raumelemente dS und dS' (H. A. Lorentz, Proc. Amsterdam 1905) findet der Verf. für die Differenz der übergehenden Wärmemengen den Ausdruck $f(r)\left(k^{\prime}-k\right) d S d S^{\prime} ; k^{\prime}$ und $k$ bedeuten das Emissionsvermögen des schwarzen Körpers bei den Temperaturen von dS' und $d S$; die Funktion $f(r)$ des Abstandes r bestimmt sich aus der Hertzschen Formeln für das elektromagnetische Feld in der Nähe eines Dipols. Für den Wärmeübergang und die Strahlung gilt die Wärmeleitungsgleichung. Das Ergebnis wird unter anderem dazu verwendet, den Anteil der Strahlung an der Wärmeleitung für einige Metalle zu diskutieren." 21

\section{Habilitace Julia Suchého na pražské české technice}

J. Suchý měl po dokončení práce zájem na její co nejrychlejší publikaci, pokud možno ještě v červencovém čísle Annalen der Physik (což se ovšem nepodařilo). ${ }^{22}$ Souviselo to

16 J. SuchÝ, O změně elektrického odporu ocelových a železných drátů při mechanickém napjetí, Rozpravy II. třídy ČAVU 14, 1910, č. 14, 13 s. + 1 př́loha s grafy.

17 Věstník ČAVU 19/2, 1910 (únor 1910), s. 74-75 (Prof. Kučera o práci p. dra Julia Suchého: „O změně elektrického odporu drátů ocelových a železných při mechanickém napjetí").

18 NHA (Haarlem, NL), cit. fond, dopis J. Suchého H. A. Lorentzovi ze 17. 9. 1910.

19 Tamtéž, srov. např. dopisy J. Suchého H. A. Lorentzovi ze 7. 3. 1911, 22. 4. 1911 a 11. 6. 1911.

20 Stanislav PetíRA, [Přehled pokroků fysiky v letech 1911 a 1912], Nauka o teple, Věstník II. třídy ČAVU 23, 1914, s. 169, citační odkaz č. 296.

21 Fortschritte der Physik im Jahre 1911, Jg. 67, II. Abteilung (Elektrizität und Magnetismus, Optik des gesamten Spectrums, Wärme), s. 326 (podepsáno iniciálami M. L.). Srov. též anotaci v Journal de Physique théorique et appliquée, 5. série, t. 2, Paris 1912, s. 335 (autor anotace zřejmě P. Job): „On a souvent supposé que la conductibilité calorifique était due, au moins en partie, au rayonnement mutuel des particules. En reprenant un raisonnement de Lorentz, M. Suchy calcule la conductibilité due au rayonnement interne seul. Il compare ses résultats aux conductibilités mesurées. Pour le cuivre, la valeur ainsi calculée est très petite par rapport à la valeur expérimentale; pour le bismuth, elle en est environ le tiers. Au contraire, pour le gaz carbonique, elle est quatre fois trop forte. (Cela tiendrait à la très grande distance, où, dans les gaz, s'excerce le rayonnement des particules.) ${ }^{\text {‘ }}$

22 NHA (Haarlem, NL), citovaný fond, dopis J. Suchého H. A. Lorentzovi z 11. června 1911. 
zřejmě již s jeho záměrem požádat o habilitaci z teoretické fyziky na české vysoké škole technické v Praze. Úvahy o potřebě prohloubení teoretické výuky v technických oborech, které $\mathrm{v}$ té době zaznívaly $\mathrm{v}$ jednáních tamních profesorských sborů, k tomu vytvářely př́íznivou situaci.

Žádost J. Suchého o udělení venia docendi pro obor teoretické fyziky byla zaprotokolována ve schůzi akademického senátu české vysoké školy technické v Praze 28. listopadu 1911. K posouzení žádosti a dalším úkonům habilitačního řízení byla zvolena komise složená z profesorů Václava Felixe (fyzik), Karla Nováka (elektrotechnik), Františka Nušla (matematik a astronom), Ludvíka Šimka (elektrotechnik) a Františka Velíska (matematik). ${ }^{23}$ Zpráva komise byla předložena až ve schůzi akademického senátu 21. ledna 1913, přednesl ji referent komise V. Felix. V zápise ze schůze bylo uvedeno, že zpráva byla schválena, ovšem s dodatkem, že kandidát musí žádat o prominutí doktorátu technických věd, a že bylo usneseno připustit kandidáta $\mathrm{k}$ habilitačnímu kolokviu. ${ }^{24} \mathrm{O}$ habilitačním kolokviu J. Suchého referoval V. Felix ve schůzi 18. února 1913. Zpráva byla vzata na vědomí a usneseno prripustit kandidáta $\mathrm{k}$ přednášce na zkoušku a vyhovět jeho žádosti o prominutí doktorátu technických věd (vzhledem k akademickému titulu PhDr.). ${ }^{25} \mathrm{~V}$ následující schůzi 10. března 1913 však bylo zaprotokolováno prohlášení komise v habilitační záležitosti J. Suchého: „Po zprávě p. prof. Dra Fr. Nušla vzato na vědomí, že bude vyžádáno dobré zdání universitního profesora dvor. rady Dra F. Koláčka o výtkách učiněných habilitační práci p. Dra Suchého v referátu komise." 26 V zápise z následující schůze 22. dubna 1913 bylo uvedeno, že profesor Nušl žádal, aby habilitační přednáška J. Suchého byla konána, „a prohlásil, že nežádá vyjádření p. dvorního rady prof. Koláčka, zmíněného v protokolu o sezeni profesorského sboru ze dne 10. března 1913“. ${ }^{27}$ Ve schůzi 27. května 1913 podal profesor Felix jménem komise zprávu o přednášce J. Suchého a skončil návrhem „aby na základě provedeného ř́zení habilitačního byla panu kandidátu žádaná venia docendi udělena“. Zpráva komise byla schválena, hlasování jako obvykle odloženo do př́íší schůze a v zápise k tomuto bodu dodáno: „K žádosti p. prof. Dra Františka Nušla bude ke spisům habilitačním připojen dopis prof. A. Einsteina, $k$ němuž vyhradil si podati své námitky p. prof. Dr. V. Felix. “28 Hlasování o návrhu, aby J. Suchý byl připuštěn za soukromého docenta teoretické fyziky na české vysoké škole technické, se konalo ve schůzi 24. června 1913; hlasovalo se kuličkami a návrh byl schválen 38 proti 8 hlasům. Do zápisu bylo zaneseno: „Pan prof. Dr. V. Felix prednesl některé posudky o habilitační práci p. Dra J. Suchého, které hodlá přiložiti ke spisům habilitačním, a podal též zprávu o své rozmluvěs $p$. dvorním radou Koláčkem o této záležitosti."29

23 Archiv ČVUT v Praze (dále AČVUT), f. Rektorát české techniky, kart. 6, Protokoly akademického senátu 1910/11-1912/13, protokol ze schůze 28. 11. 1911, bod 9.

24 Tamtéž, protokol ze schůze 21. 1. 1913, bod 11. Mezitím bylo ve schůzích akademického senátu projednáno a schváleno jmenování mimořádného profesora obecné a technické fyziky Václava Felixe profesorem řádným (ve schůzi 11. 1. 1912) a ustanovena komise k vypracování návrhů na zř́zení a obsazení druhé stolice fyziky (ve schůzi 5. 7. 1912), která však žádný návrh nepředložila v podstatě až do roku 1918.

25 Tamtéž, protokol ze schůze 18. 2. 1913, bod 11.

26 Tamtéž, protokol ze schůze 10. 3. 1913, bod 11 .

27 Tamtéž, protokol ze schůze 22. 4. 1913, bod 13

28 Tamtéž, protokol ze schůze 27. 5. 1913, bod 9.

29 Tamtéž, protokol ze schůze 24. 6. 1913, bod 5. 
Strohé zápisy v citovaných protokolech ze schůzí akademického senátu může doplnit před lety náhodně objevený (a dnes již opět nezvěstný) dokument s několika rukopisnými poznámkami profesora V. Felixe k habilitaci J. Suchého, datovaný 24. června 1913. V. Felix v něm odkazoval ke schůzi ,profesorského“ sboru 27. května [1913], v němž profesor Nušl předložil príípis profesora A. Einsteina datovaný 15. července 1912 „a tvrdí, že tento posudek znamená proti mojí [Felixově] recensi neobyčejnou chválu práce dra Suchého. K tomu odpovídám:

1) Př́pis prof. Einsteina - jakož stojí hned v první rádce - byl vyžádán od Dra Suchého. Má tudiž podle mého miněni menší cenu než spontánní projev uveřejněný tiskem. Prof. Einstein dosud nikde posudek tiskem nevydal.

2) Posudek prof. E. shoduje se celkem s mojí recensí. Uznává, že vlastní těžiště práce je $v$ applikacích vět Lorentzových, $k$ čemuž je třeba značné duševni energie (moje recense: ,po této stránce jsou výsledky jeho (Suchého) práce pěkné), kdežto experimentální zkoušení považuje prozatím za vyloučeno.

Rozdil nazírání je ten, že prof. E. klade veliký důraz na zavedení tzv. sálání druhého druhu (,Strahlungsübertragung zweiter Art') čili nepřimočarého (, ungeradlinige Strahlung '), což považuji za osobni stanovisko páně E. tak dlouho, pokud nebude onen druhýdruh sálání experimentálně prokázán. " Dále V. Felix uvedl, že prohlédl dobovou odbornou literaturu anglickou, francouzskou a německou, citoval referáty o Suchého práci v Journal de Physique, Fortschritte der Physik a v Chemische Zentralblatt a konstatoval: „Z těchto posudku žádný neobsahuje nic podobného jako posudek prof. Einsteina." ${ }^{30}$

Výtky činěné Suchého habilitační práci reflektovaly zjevně postoj profesora F. Koláčka a v habilitačním řízení na pražské české technice byly uplatněny Koláčkovým žákem V. Felixem. V roce 1912, v situaci stagnujícího habilitačního řízení, požádal J. Suchý o posudek na svou práci Alberta Einsteina, který $\mathrm{v}$ té době ještě působil jako profesor teoretické fyziky na pražské německé univerzitě. ${ }^{31}$ Mohlo to být na radu H. A. Lorentze, mezi nímž a A. Einsteinem existovaly úzké profesní kontakty a prátelství. ${ }^{32}$ Navázání kontaktu mohla napomoci okolnost, že J. Suchý a A. Einstein byli vrstevníci a bydleli na Smíchově nedaleko sebe: A. Einstein v Lesnické ulici a J. Suchý v Kobrově ulici u Kinského zahrady, kam Einstein chodíval se svými syny na procházky.

Einsteinův rukopisný posudek, datovaný 15 . července 1912, byl opatřen kulatým razítkem Ústavu teoretické fyziky Německé univerzity v Praze, což mu dodávalo oficiální charakter. Einsteinovo hodnocení Suchého práce bylo pro Suchého kritiky v českých akademických kruzích zjevně velkým, možná i nemilým překvapením. Vyjádření autority formátu A. Einsteina však nebylo možné rozporovat. Habilitace J. Suchého byla schválena a výnosem rakouského ministerstva kultu a vyučování z 28. srpna 1913 potvrzena; $v$ té době již ovšem Einstein Prahu opustil. V souhrnu v aktech ministerstva bylo $k$ Suchého habilitaci

30 Česká vysoká škola technická, Kniha otisků pro záležitosti knihovní 1907-1926, s. 88. Citováno podle opisu, který v roce 1979 pořídila knihovnice Fakulty elektrotechnické ČVUT dr. K. Ondrášková.

31 A. Einstein post na pražské německé univerzitě a Prahu opustil 25. července 1912 . Z nepřeberné literatury o A. Einsteinovi a jeho pobytu v Praze bych ráda připomněla v prvé řadě pionýrský, o archivní prameny opřený článek Jan HavrÁNEK, Ke jmenování Alberta Einsteina profesorem v Praze, Acta Universitatis Carolinae - Historia Universitatis Carolinae Pragensis 17/2, 1977, s. 105-130. Viz též J. Ratajová, zde ve svazku, s. 175, pozn. 2.

32 Pro korespondenci H. A. Lorentze a A. Einsteina z doby Einsteinova působení v Praze viz Martin J. KLEIN A. J. Kox - Robert Schulmann (eds.), The collected papers of Albert Einstein, V, The Swiss years: correspondence, 1902-1914, Princeton University Press 1993. 
lakonicky konstatováno, že předložený habilitační spis „,wird im Allgemeinen günstig beurteilt, wenngleich im Detail die Anschaungen des Prof. Felix und Nušl divergieren".33

Dodejme, že F. Koláček, který byl již delší dobu nemocný, 8. prosince 1913 zemřel. Jeho nástupcem na pražské české univerzitě se stal jeho věrný asistent František Záviška, který se zde habilitoval pro teoretickou fyziku již v roce 1906 na základě práce vykonané pod Koláčkovým vedením. Poté, v letech 1906-1908, absolvoval zahraniční stáž u J. J. Thomsona na univerzitě v Cambridgi, jejímž výsledkem byla experimentální práce o vlivu rentgenového záření na kondenzaci vodních par ve Wilsonově mlžné komoře, dopracovaná také až po návratu a publikovaná v roce 1909 v Rozpravách ČAVU. ${ }^{34}$ Připomeňme, že F. Záviška během své další kariéry patřil $\mathrm{k}$ neochvějným zastáncům a popularizátorům Einsteinovy teorie relativity.

\section{Další profesní kariéra Julia Suchého}

J. Suchý konal docentské přednášky na české technice v Praze zprvu při svém pokračujícím působení na střední škole. Vedle toho přednášel např. i ve Spolku českých inženýrů a architektů. $Z$ těchto a dalších príležitostných přednášek vzešel jeho spisek Moderni názory o podstatě elektřiny a hmoty, vydaný v roce 1917 vlastním nákladem (rozsah 68 stran). ${ }^{35}$ Počátkem roku 1918 požádal J. Suchý o úlevu z povinností na střední škole a v dalším roce pak již o plnou dovolenou ,za účelem vykonávání docentury na technice a umožnění činnosti vědeckée“. 36

Po vzniku samostatného Československa se začala profesní kariéra J. Suchého slibně rozvíjet. Ve školním roce 1918/1919 byl zvolen zástupcem v akademickém senátu pražské české techniky a pověřen budováním druhé profesury fyziky. Jeho docentské přednášky z teoretické fyziky byly od počátku tohoto školního roku honorovány (taxou $400 \mathrm{~K}$ za jednu semestrální hodinu). Na jaře 1919 byl ministerstvem veřejných prací na návrh Svazu

33 NA, f. MKV-R, kart. 247, i. č. 87, sign. 7, Professoren Prag, spis č. 38.279/1913.

34 František ZÁvišKA, O vlivu silného Roentgenova záření na kondensaci vodních par, Rozpravy II. tř́ídy ČAVU 18/8, 1909, $31 \mathrm{~s}$.

35 V Národní knihovně v Praze se dochoval výtisk s vepsaným věnováním autora profesoru Františku Drtinovi. V roce 1918 vyšel spisek v druhém vydání. V dobovém kontextu upoutají především slova J. Suchého v závěru spisku: „Kdyby se lidstvu zdařilo zužitkovati jen zcela malý díl ohromné této energie, utajené v nitru atomu, rozevřely by se perspektivy možností nedozírných. Snad bychom byli, mimo jiné, zbaveni starostí, co pak, až všechny uhelné doly budou vyčerpány. Prozatím arci nemáme naději na zužitkování energie intra-atomické. Než, kdo dovede říci, jakými překvapujícími cestami půjde další vývoj?“" (Citováno ze s. 63.)

$36 \mathrm{~V}$ tištěných programech přednášek české vysoké školy technické (vydávaných s předstihem) byly docentské přednášky J. Suchého uvedeny poprvé ve školním roce 1914/1915, a sice „Elektřina a hmota: přehled moderních teorií“ (týdně 2 hodiny). Stejnou přednášku ohlásil na školní rok 1916/1917. Na školní rok 1917/1918 ohlásil přednášky „Pohyb kmitavý a jeho technické aplikace“ v zimním semestru a „Theorie měření fysikálně-technických“v letním semestru (v obou případech v rozsahu 3 hodin týdně). V programu na školní rok 1918/1919 bylo jméno J. Suchého uvedeno u přednášky v zimním semestru „Theorie měření technických, zvláště mechanických, thermických a optických“ (3 hodiny). Přednášky „Theorie záření a její technické užití“ ( 2 hodiny) a „Theorie elektronová a elektrická theorie hmoty“ (1 hodina), ohlášené na letní semestr, byly uvedeny bez jména přednášejícího, což zřejmě souviselo s pověřením J. Suchého zajištěním výuky pro druhou profesuru technické fyziky. Na školní rok 1919/1920 bylo jeho jméno uvedeno u přednášek „,Theoretické dodatky ku fysice technické a obecné elektrotechnice“ (3 hodiny v obou semestrech) a „Theorie záření“ (2 hodiny v letním semestru), na školní rok 1920/1921 u přednášek „Látky radioaktivní“ (2 hodiny v zimním semestru) a „Radioaktivita a elektronová theorie hmoty“ (2 hodiny v letním semestru). Ve školním roce 1920/1921 byl J. Suchý uveden také jako suplent stolice fyziky na Čs. státní vysoké škole obchodní (2 hodiny přednášek a 2 hodiny cvičení). AČVUT, Programy české vysoké školy technické v Praze, studijní roky 1913/1914-1920/1921. 
pro zkoušení technicky důležitých látek a konstrukcí pověřen také vypracováním návrhu na vybudování československého radiologického ústavu. Koncepční návrh (memorandum) předložil 18. května 1919 a v následujících měsících, po konzultaci v Institut für Radiumforschung ve Vídni, návrh rozpracoval do velkoryse koncipovaného projektu. ${ }^{37}$ Státní radiologický ústav RČS byl oficiálně zř́zen rozhodnutím ministerské rady RČS z 8. srpna 1919 jako resortní ústav ministerstva veřejných prací; J. Suchý byl jmenován přednostou ústavu 5. prosince 1919 na základě dekretu ministra resortu. Krátce na to, dekretem prezidenta T. G. Masaryka z 26. prosince 1919, byl J. Suchý s účinností od 1. ledna 1920 jmenován také řádným profesorem fyziky na české technice v Praze. Šlo o nově systemizovanou druhou profesuru fyziky, spojenou s výukou fyziky pro strojní a elektrotechnické inženýrství a chemicko-technologické inženýrství; J. Suchý se tak stal oborovým kolegou (a při boji o prostorové a finanční zajištění druhého fyzikálního ústavu i soupeřem) V. Felixe. V březnu 1920 se J. Suchý stal také znalcem I. (prírodovědného) odboru Masarykovy akademie práce, jako jeden z prvních šedesáti znalců této nové technické akademie jmenovaných vládou.

Na nově ustanovených postech působil však J. Suchý jen krátce. Dne 19. srpna 1920 tragicky zahynul při nerozvážném naskakování do rozjeté pražské tramvaje. Jeho nástupcem ve vedení Státního radiologického ústavu byl jmenován nejprve B. Kučera, který však16. dubna 1921 rovněž nečekaně zemřel (na srdeční selhání, dř́ve než převzal jmenovací dekret); poté byla správa ústavu svěřena vědeckému kuratoriu v čele s V. Felixem. V. Felix souběžně zastával svou profesuru fyziky na pražské české technice a vedle toho suploval i druhou profesuru fyziky po J. Suchém, a to až do jejího nového obsazení Františkem Nachtikalem v roce 1926. F. Nušl byl v červnu 1920 poveř̌en správou a od 1 . dubna 1924 jmenován ředitelem státní hvězdárny v Praze; v souvislosti s tím se v březnu 1924 vzdal profesury na technice. Za soukromé docenty teoretické fyziky na pražské české technice byli v roce 1921 připuštěni Karel Teige a Viktor Trkal, který se právě vrátil z ročního studijního pobytu u Paula Ehrenfesta na univerzitě v Leidenu. K. Teige získal na pražské české technice učební př́kaz pro teoretickou fyziku, V. Trkal se v roce 1921 habilitoval na pražské české univerzitě, kde byl rok na to jmenován mimořádným profesorem teoretické fyziky. A pokud jde o V. Posejpala, ten byl na pražské české univerzitě jmenován profesorem experimentální fyziky (1919 mimořádným a 1921 řádným), stal se významným reprezentantem české fyziky v mezinárodních institucích, jeho vědecké práce však byly předmětem řady diskusí v domácích odborných kruzích.

\section{Príloha}

V německém originálu a bez dalšího komentáře připojujeme přepis devíti rukopisných dopisů J. Suchého H. A. Lorentzovi, které se datují do doby po jeho návratu ze studijního pobytu $\mathrm{v}$ Leidenu do dokončení a publikace $\mathrm{v}$ Leidenu započaté práce. Přepis byl proveden podle kopií dopisů, které jsou v originále uloženy v písemné pozůstalosti H. A. Lorentze

37 Návrh na vybudování radiologického ústavu a pověření J. Suchého a asistenta stolice anorganické chemie Kamila Kohna prozatímně měřeními v tomto ústavu byl předložen ministerstvu veřejných prací Svazem pro zkoušení technicky důležitých látek a konstrukcí. Návrh byl datován 28. dubna 1919 a podepsáni pod ním byli předseda anorganické sekce Svazu J. Milbauer a předseda Svazu K. Špaček, oba profesoři pražské české techniky. Další kontext E. TěšínsKÁ, Dějiny jaderných oborů v českých zemích (Československu). Data a dokumenty (1896-1945), Praha 2010, s. 389-395. 
v Noord-Hollands Archief v Haarlemu. Za poskytnutí kopií dopisů děkujeme vedení archivu, jmenovitě pak paní Godelieve Boltenové.

Text dopisů je uveden v plném znění, s výjimkou dopisu pod číslem 4, v němž jsou vypuštěny popisy přístrojů uveřejněné J. Suchým ve výroční zprávě české reálky na Malé Straně za školní rok 1909/1910 (srov. poznámku 6); pro ilustraci je uveden jen popis př́ístroje pod číslem II.

Odpovídající dopisy H. A. Lorentze J. Suchému, pokud se dochovaly, se zatím nepodařilo objevit.

\section{Ediční poznámka}

Při přepisu dopisů byl (na rozdíl od edice dokumentů připravené J. Ratajovou) zachován dobový pravopis, s některými archaickými, dnes neobvyklými jevy (jako např. psaní „i“ na místo ,ie“ (,anticipiren“, „publizirt" nebo ,komplizirten“); psaní „ae“ místo ,ä“ (,Aerztin“) nebo „ue“ místo , ̈̈“ („Ueberraschendes“), psaní zdvojeného „,ss“ na místo „ß“

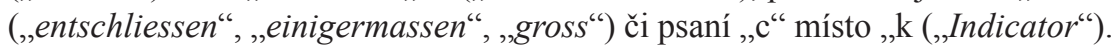

V původní podobě, bez rozepisování, jsou ponechány i v dopisech uváděné zkratky a také různé způsoby zápisu data v záhlaví dopisů (včetně koncové tečky).

Nerozluštěná nebo sporná slova jsou označena otazníkem.

Dopis č. 1: J. Suchý H. A. Lorentzovi, 4. 12. 1909

Hochgeehrter Herr Professor!

Smíchov 4. 12. 09.

Vielleicht haben Sie sich gewundert, dass ich so lange von mir nichts hören lasse. Der Grund davon ist dieser. Meine Arbeit ist aus Ursachen, über die ich heute schreiben will, noch nicht fertig; schon viele Wochen dachte ich daran, Ihnen wenigstens einen Brief zu senden, um Sie zu informieren. Aber ich wollte Ihnen ersparen, diesen Brief lesen zu müssen, denn es sind unerfreuliche Tatsachen, über die ich berichten muss. Jetzt, da ich sehe, dass meine Arbeit im günstigen Fall erst nach einigen Wochen fertig sein kann, habe ich mich doch entschlossen, Sie über meine Situation zu benachrichtigen, denn sonst würden Sie kaum mein Handeln begreifen können. Im Voraus bemerke ich dass ich in diesem Brief Manches nur berühren kann, Anders nicht einmal erwähnen kann.

Um gleich das Resultat zu anticipiren, er ist ein Unglück für mich, dass ich meine Arbeit nicht in Leiden beendigen konnte. Denn gleich nach meiner Rückkehr erwartete mich hier so viel Ueberraschendes und Unangenehmes, dass ich nicht einmal in den Ferien zur ruhigen Arbeit kommen konnte. Der Schwiegervater hat sich von Neuen verheiratet. Meine Frau war krank und geht noch jetzt zum Arzte. Dem Bruder musste eine Stellung gesucht werden. Unter einigen Prof. der Univ. hat jemand die boshafte Sage verbreitet, dass mein Aufenthalt in Leiden resultatlos gewesen ist. Das hat mich sehr beunruhigt und geärgert.

Mein, von Proff. Koláček und Kučera begünstigter, sit venia verbo „Konkurent“ in der Habilitation, Dr. Posejpal, kam gleichzeitig mit mir aus Paris zurück und brachte eine gedruckte Arbeit mit (Ann. de Phys. et Ch., in den Sommermonaten). Infolgedessen konnte er gleich nach den Ferien um Habilitation ansuchen und ist mir gegen alles Erwarten zuvorgekommen - falls es zu meiner Habilitation überhaupt noch kommen wird. 
Vor meiner Abreise rieten Sie mir, Herr Professor, zu Prof. Koláček zu gehen. Dazu konnte ich mich lange nicht entschliessen, obwohl auch Prof. Strouhal dazu geraten hatte. Erst vor einigen Wochen besuchte ich ihn, um endlich seine Wünsche betreffe der „Př́bramer“ Arbeit zu erfahren. Die Arbeit soll also etwa auf die Hälfte gekürzt. Nur wie? Viel ernster ist aber Folgendes. Als ich von meiner Leidener Arbeit sprechen wollte (er wusste noch gar nicht das Thema), unterbrach er mich heftig: „Wenn es aus der Elektronentheorie ist, dann können Sie herausbekommen, was Sie nur wollen. Was man am Anfang in die Gleichungen hineinlegt, das kommt ja am Ende wieder hinaus." Das Thema, antwortete ich darauf, basirt auf der Strahlungstheorie, die Resultate sind natürlich auch für die Elektronentheorie einigermassen interessant. Übrigens haben sich die Annahmen der Elektronentheorie, wie der Strahlungstheorie, schon vielfach bewährt. Auch stimmen die Resultate meiner Arbeit (z. B. Schätzung der molek. Dimens.) mit anderwärtigen Schätzungen gut überein, sind also plausibel..., „Das ist Alles einerlei“ war die einzige Antwort. Meine Arbeit, an der ich lange genug gearbeitet hatte, so a priori, ungelesen, verurteilt zu sehen, das musste mich ja ordentlicherweise deprimiren! Nicht etwa deshalb, das ich die Richtigkeit solcher Kritik einsehen würde, aber parktisch ist es für mich ominös genug. Wenn man jemandem systematisch und lange Zeit hindurch jedwede - auch die geringste - Anerkennung und Ermutigung absagt, dann muss es ja psychisch hemmend wirken. Und wenn ich wenigstens die Genugtuung hätte, zu sehen, dass die „offiziell“ bei uns anerkannten und geförderten jüngeren Physiker wirklich viel gescheiter sind, als ich!

Prof. Kučera ist jetzt nach eigener Aussage auch gegen mich, angeblich, weil ich mit der bekannten (seiner) Kritik meiner älteren Arbeit nicht zufrieden war und dieselbe in einem Briefe (!!) welchen er zu Gesicht bekommen haben soll, ungerecht nannte. Dies ist doch charakteristisch genug. Nur tut mir leid das ich nicht mehr weiss, ob ich in diesem Sinn, und wem von den zwei oder drei Herren, die in Betracht kommen könnten geschrieben habe. Jedenfalls hätte ich volles Recht dazu! Ausserdem sucht er mich in kleinliche Affären einzuwickeln.

Solche und ähnliche andere peinliche Ereignisse, die sich nach meiner Rückkehr aus Leiden rasch aufeinander ereigneten, machten mich bald arbeitsunfähig. Ist es auch zu verwundern? Die Schule trug das Uebrige bei. Sie nimmt mir die besten Tagesstunden weg und erschöpft bei unseren enormen Schülerzahlen in den Klassen wirklich bedeutend.

Und so weiss ich jetzt wirklich nicht, wie das Alles endigen soll, und bin oft schon ganz verzweifelt. Soll meine Arbeit ohne jedes erfreuliche Resultat endigen? Die Zeit, die ich in Leiden verbrachte, war aus mancherlei Gründen eine recht schwere für mich, und ich denke wirklich nicht gern darauf zurück! Glauben Sie mir, hochgeehrter Herr Professor, ich würde noch heute Alles über Bord werfen und würde mich weiterhin um gar nichts mehr kümmern - wenn ich nur die Natur darnach hätte. Es ist mir, als würde mein Leben den Sinn und Grund verlieren, wenn ich aufhörte, wissenschaftlich tätig zu sein.

Doch genug darüber, über solche Sachen ist schwer zu schreiben, und ich berühre es heute überhaupt nur aus dem Grunde, um Ihnen einen richtigen Einblick in meine Lage zu ermöglichen.

Hoffentlich werden sie jetzt - in Erwägung aller dieser Umstände - mein „Schweigen“ begreifen und auch gütigst entschuldigen!

Wie sollte ich mich am besten zu der Arbeit von Jeans in der Juni-Nummer der Phil. Mag. stellen? Sind Ihnen, Herr Professor, etwa noch andere einschlägige Arbeiten, bes. aus 
der letzten Zeit bekannt? Mit dem Zeitschriftenlesen habe ich hier nämlich einige Schwierigkeiten. Die Notiz von Reinganum (über die Arbeit von Jeans) in der Phys. Zeitschr., September 1909, habe ich gelesen.

Ich danke Ihnen nochmals bestens für die grosse Aufopferung und Mühe während meines Aufenthaltes in Leiden! Ich bedauere so oft das mein Urlaub in eine so ungünstige Zeit fallen musste, und dass ich nicht in diejenigen Gebiete eingearbeitet war in welchen ich dann arbeiten sollte.

Indem ich noch um Entschuldigung bitte, dass dieser Brief, länger ausgefallen ist, was schon der Sachverhalt mit sich brachte, bleibe ich in vorzüglichster Hochachtung und mit höflichsten Empfehlungen an die hochgeehrte Familie, Ihr dankbar Ergebenst

Jul. Suchý.

Dopis č. 2: J. Suchý H. A. Lorentzovi, 17. 5. 1910

Smíchov 17. 5. 1910.

Hochgeehrter Herr Professor!

Zuerst bitte ich, meinen Dank für den liebenswürdigen Brief und die in ihm bekundete Teilnahme entgegenzunehmen!

Von Alledem, was mir nach meiner Rückkehr aus Leiden zugestossen ist, habe ich Ihnen nur sehr unvollständig berichten können. Namentlich war die Aufführung der Herren Koláček und Kučera noch viel schlimmer, und Manches wollte ich Ihnen absichtlich nicht schreiben. Vieleicht wird mir später ?gegenüber sein, mit Ihnen persönlich sprechen zu können.

Was meine Kleinigkeit anbelangt, so habe ich recht viele Fehler, wie übrigens die meisten Sterblichen. Aber ich bin mir wirklich keiner tragischen „Schuld“ bewussst, besonders keiner solchen, die Alles das rechtfertigen würde, was mir in den letzten Jahren von Menschen zugestossen ist. Kein Wunder, das man das Vertrauen zu Anderen, sowie das Selbstvertrauen verliert; dass man resignirt wird*). Und wenn man sieht, wie unerhörte Intrigen auch einigen anderen jüngeren Adepten das Leben verbittern so muss man dem Satz beistimmen, dass die Wissenschaft auf die moralische Gesinnung der Menschen wirklich ohne Einfluss ist.

Was meine Frau anbelangt, so geht es Ihr seit Dezember, wenn ich zuletzt geschrieben habe, natürlich schon besser, obwohl Sie noch stets ihre Aerztin besuchen muss. Es handelt sich, wie sich herausgestellt hat, um ein Kombinirtes chronisches Frauenleiden. Hoffen wir, dass es ohne schlimme Folgen vorübergehen wird. Meine arme Frau war mir eine treue Stütze in schweren Tagen, Sie musste, da sie die Verhältnisse im Ganzen kennt, Alles das mit mir durchmachen und durchfühlen. Und darüber noch - so viel Familienunglück!

Doch nun zur Sache, die noch unerledigt bleibt. Was meine Abhandlung betrifft, so verspreche ich, dieselbe so bald als möglich Ihnen zu senden. Ich werde mich darauf beschränken, was fertig ist. Es wäre dies schon geschehen, wenn ich seit Februar nicht andauernd kränklich gewesen wäre. Ich konnte nur mit Mühe lehren und mehrere Stunden sprechen da ich stets von Katarhen heimgesucht wurde, die sich noch verschieden Komplizirten. Noch nach dem Erhalten Ihres geschätzten Briefes dauerte dies fort, ich musste eine Woche zu Hause bleiben. Infolgedessen kam ich nicht vorwärts. In den allerletzten Wochen musste ich - leider - in das heutige Schulprogramm eine kürzere Abhandlung schreiben der 
Schuldirektor drängte auf mich. Ich werde im Programm einige Demonstrationsapparate beschreiben, die ich in früherer und letzter Zeit konstruirte. Es ist selbstverständlich nur eine Kleinigkeit. Soeben bin ich damit fertig. Wenn ich mit der Abhandlung soweit fertig sein werde, dass ich dieselbe an Sie senden kann, weiss ich vorläufig nicht. Aber seien Sie überzeugt, dass es wirklich so bald als möglich geschehen wird, soweit meine Zeit es zulässt, denn niemand wäre froher als ich, wenn diese Abhandlung schon publizirt wäre! Das werden Sie mir, Herr Professor, gewiss zugeben. Dadurch soll ja neue Situation geschaffen werden.

Mit besten Empfehlungen und vollkommener Hochachtung Ihr ganz Ergebener Jul. Suchý.

*) P.S. Ich bemerke noch, das die Akademie bis jetzt meine Prríbramer Arbeit nicht publizirte! Das braucht wohl kein Kommentar. „Offiziell“" würde man es natürlich ganz unschuldig erklären durch nötige Formalitäten oder schlechte Organisation der Kanzlei!

Dopis č. 3: J. Suchý H. A. Lorentzovi, 31. 7. 1910

Kremnier 31. 7./ 910.

Hochgeehrter Herr Professor!

Ich erlaube mir hiemit Ihnen zu melden, dass ich heute meine Abhandlung Ihnen übersandt habe. Da dieselbe als Postcolli aufgegeben werden musste, so wird es voraussichtlich 5-6 Tage, bevor Sie ankommt. Brief, Separate etc. liegen bei. Da der Bote aus Versehen die Sendung ohne sogen. Rückschein aufgegeben hat, so wäre ich Ihnen verbunden, wenn Sie gefälligst durch einige Zeilen auf einer Postkarte mir den richtigen Empfang der Sendung bestätigen würden. Ich weiss auch nicht, ob Sie sich jetzt in Leiden aufhalten; ich bitte um event. Mitteilung der Adresse.

Da Näheres schon in dem, der Sendung beigegebenen Brief mitgeteilt, beschliesse ich und verbleibe Ihr Hochachtungsvoll Ergebener u. dankbarer

Jul. Suchý

\section{Kremnier, Bělidla 93.}

B! Zugleich möchte ich einer Fehler berichtigen, der ich in die „Bemerkungen“, die ich zum Manuskript beigefügt habe, eingeschlichen hat. Beim Wiederschreiben derselben schien es mir, dass man die Formel 109) der Abschn. VII: $P / x=F(n, u)$ auch anders, durch Anschluss an eine Formel des Kap. IV hätte ableiten können. Dies ist aber nicht der Fall, aus dem einfachen Grunde, weil Kap. IV, die fiktiven elmot. Kräfte voraussetzt, VII. dagegen dieselben eliminirt. Dies habe ich übersehen. Wahr ist nur, dass die obige Formel und diejenige aus IV: $P=16 \pi \mathrm{kj} d n$ einander gegenseitig verifiziren da sie zum demselben Resultat führen.

Dopis č. 4: J. Suchý H. A. Lorentzovi, 17. 9.1910

Smíchov 17. 9. 10.

Hochgeehrter Herr Professor!

Da Sie so gefällig waren, sich um die in der Programmabhandlung beschriebenen Vorlesungsversuche zu interessiren, so erlaube ich mir heute, dieselben kurz wiederzugeben. Es sind nur Kleinigkeiten, Nebenergebnisse meiner kurzen Unterrichtspraxis. 
I. Apparat zur Demonstration der Aenderung des Gewichts eines fallenden Körpers [...]

II. App. für Versuche über strahlende Wärme. Das soll ein einfacher und viel billigerer Ersatz des bekannten Melloni'schen Apparates sein, welcher für unsere Dotationen recht teuer ist. Sowohl die Wärmequelle, als auch der „Rezeptor“ sind anderer Art, als üblich. Alle Wärmequelle dient einfach ein ausgiebiger Bunsenbrenner (eigentlich zwei verschiedene, für „lineare“ u. für Flächenförmige Flamme), der auf nichtleuchtende Flamme regulirt wird. Die etwa noch übriggeblieben Lichtstrahlen werden durch zwischengelegte rote Glasscheiben absorbirt, sodass man mit reinen Wärmestrahlen operirt. Als Rezeptor oder Indicator der Strahlen fungirt ein Radiometer. Trotz der Einfachheit des Ganzen ist die ?Einrichtung ziemlich empfindlich und man kann damit Folgendes demonstriren: Nachweis der geradlin. Fortpflanzung, Reflexion und auch das Gesetz der Reflexion $(\alpha=\beta)$ der Strahlen, Diffusse Reflexion, Emission der W[ärme]-Str[ahlen] unter der Draper'schen Grenze, Absorption, Verschiedenheit des Verhalten der Körper in Bezug auf Durchsichtigkeit und ? Diathermasie (Steinsalz-, Eis-, Ebonitplatten etc).

III. App. zum Nachweis des Ges. von Biot-Savart. [...]

IV. Demonstration der Frequenzbestimmung des Wechselstromes auf Grund der akustischen Resonanz. [...]

Dies wäre also kurz der Inhalt jener Abhandlung. Leider sind diese Programmabhandlungen sehr wenig verbreitet an. Wenn ich wüsste, dass es dafür steht, würde ich es noch anderwärts publizieren, event. übersetzen. Am liebsten möchte ich jetzt aber etwas Neues anfangen. Zwar habe ich den „halben“ Urlaub, von dem ich in dem der Sendung beigelegten Brief geschrieben, nicht erhalten (Grund vorläufig unbekannt, vielleicht auch nur Mangel an Geld), aber Etwas möchte ich doch gerne beginnen, falls nämlich die Abhandlung über Wärmestrahlung von Ihnen als reif zur Publikation angesehen wird, d. h. wenn Aenderungen, auf die ich gefasst bin, eine nicht zu lange Zeit beanspruchen. Prof. Strouhal hat mich gestern bei meinem Besuch u. A. gefragt, ob ich diese Abhandlung nicht in der Wiener Akademie, und erst darnach in den Annalen d. Ph. abdrucken könnte. Wenn Sie, Herr Professor, dafür wären, so wäre auch ich damit ganz einverstanden, aber nur unter der Bedingung, wenn Sie der Ansicht sind, dass in Wien die Abhandlung der Gefahr einer event. schiefen Beurteilung nicht ausgesetzt wäre. Sie werden wohl bereifen können, Herr Professor, dass ich infolge der schon gemachten schlimmen Erfahrungen einigermassen misstrauisch geworden bin! Auch anderen ist hier in letzter Zeit Verschiedenes rassist, was auf die Objektivität einiger hiesigen Herren ein sonderbares Licht wirkt. Die Wiener Verhältnisse aber kenne ich nicht so weit. Es ist mir viel daran gelegen, dass die Arbeit schnell und sicher, d. h. anstandslos publizirt wird! Deshalb bitte ich um gef. Mitteilung Ihrer Ansicht, ich und auch H. Prof. Strouhal wird mit jeder Lösung der Frage zufrieden; nur in der hiesigen Akademie will ich es nicht einreichen.

Interessant zu bemerken ist, dass nach der „Phys. Review“ ein amerikanischer Physiker die Versuche der Habilitationsarbeit des H. Posejpal, welchen Prof. Koláček so gefördert hat, wiederholt hat, ohne aber die fraglichen Erscheinungen beobachten zu können. Und auf Grund dieser (Übrigens einziger von Referaten und Artikeln abgesehen) Arbeit wurde die Habilitation glatt durchgeführt.

Anfang Oktober lagt der Kältekongress in Wien. Sollte jemand von meinen Leidener Bekannten über Prag nach Wien fahren, so würde mich es freuen, wenn es mich besuchen würde. 
Für den Herrn Sohn erlaube ich mir eine kleine Kollektion von Jubiläumsmarken, die zum 18. 8. 910 in beschränkten Anzahl herausgegeben werden und jetzt schon selten werden, beizulegen.

Die Schule hat schon vorige Woche begonnen. Die Ferien waren heuer kalt und verregnet. In Mähren endeten sie mit grosser Überschwemmung. Cholera haben wir in Prag nicht auch in Wien haben die Besucher kaum etwas zu befürchten, da bisher nur ganz sporadische Fälle vorgekommen sind. Zu einer Epidemie wird es wohl nicht mehr kommen.

Der Brief ist lang geworden, obwohl ich die Beschreibung der Versuche nur flüchtig zu gestalten bestrebt war! Ich verliebe mit besten Empfehlungen Ihr, in vollkommener Hochachtung und Dankbarkeit

Ergebener

Jul. Suchý

Dopis č. 5: J. Suchý H. A. Lorentzovi 26. 12. 1910

Smíchov 26. 12. 1910.

Hochgeehrter Herr Professor!

Da ich bisher die im August d. J. mir von Ihnen gefällig versprochene Antwort nicht erhalten habe, und der am 17. 9. von mir gesandte Brief ebenfalls unbeantwortet blieb, so erlaube ich mir hiemit höflichst anzufragen, worin die Ursache davon liegt? Ich hoffe, dass Sie sich, hochgeehrter Herr Professor, in meine Lage hineindenken, und mir diese Urgenz nicht etwa übelnehmen werden! Denn ich weiss mir wirklich keinen anderen Rat, als mich von Neuen an Sie zu wenden!

Obwohl schon in meinem Brief davon die Rede war, möchte ich nochmals bemerken, dass es mir gleichgültig ist, in welcher Akademie die Abhandlung vorgelegt wird, und dass ich dies vollständig Ihrem Ermessen überlasse. Auch könnte dieselbe gleich in den Annalen publizirt werden, ohne früher in einer Akademie vorgelegt zu werden. Eigentlich wäre es das Natürlichste, wenn die Arbeit in Holland, wo sie entstanden ist, publizirt würde. Aber dies stosst auf Sprachenschwierigkeiten. Nur in der hiesigen Akademie will ich meine Abhandlung nicht vorlegen, wenn ich mir neue recht unangenehme Erfahrungen ersparen will.

Wen Sie die diesbezüglichen Verhältnisse aus unparteiischer Quelle kennen lernen möchten, so könnte ich Ihnen, Herr Professor, einige Adressen von Univ.-Professoren angeben, die nicht zu der fraglichen Clique gehörig und andere Wissenszweige vertretend, Ihnen gewiss objektiv bezeugen würden, wie es hier in der Akademie, speziell in der II. Klasse (math.-naturw. K1.) aussieht; Sie würden sicher hören, dass meine Schilderung durchaus nicht übertrieben ist. So Manches wird angeblich aus nationalen Gründen totgeschwiegen!

Zum Schluss erlaube ich mir Ihnen meine herzliche Gratulation zur Mitgliedsernennung in der Pariser Akademie auszusprechen! Auch zum bevorstehenden Jahreswechsel wünsche ich Ihnen, hochgeehrter Herr Professor, Alles beste! Indem ich nochmals um baldige Antwort und Aufklärung höflich bitte, verbleibe ich Ihr

Hochachtungsvoll Ergebener

Jul. Suchý. 
Hochgeehrter Herr Professor!

Anfang Januar erhielt ich Ihren liebenswürdigen Brief, in dem Sie die Hoffnung ausgesprochen haben, dass Sie mit der Lektüre meiner Abhandlung in den Weihnachtsferien fertig sein werden. Da seit dieser Zeit wieder zwei Monate verflossen sind, so erlaube ich mir hiemit höflichst noch einmal anzufragen, ob Sie, hochgeehrter Herr Professor, die Arbeit schon durchgelesen haben? Ich würde Sie mit dieser Anfrage wirklich nicht belästigen, wenn es nicht geradezu eine wichtige Lebensfrage für mich wäre, dass diese Abhandlung, die ja das Resultat meines Leidener Aufenthalts darstellt und an der ich lange genug gearbeitet habe, endlich publizirt wird. Vielleicht hätte ich heute trotz alledem nicht geschrieben, da ja Ihnen Alles das, was ich sagen will, gut bekannt ist, wenn mir einige von meinen Lehrern nicht geraten hätten, dass ich mich von Neuem an sie, Herr Professor, wende!

Ich muss bemerken, dass mir diese Sorgen schon lange Ruhe rauben. Selbst wenn meine Arbeit schon publizirt wäre, wäre meine Situation, bei der prinzipiell ablehnenden Haltung von Prof. Koláček, schlimm genug! So aber wird noch hartnäckig behauptet, dass mein Urlaub resultatlos verlaufen sei - und ich kann mich nicht gut dagegen wehren, solange die Abhandlung nicht gedruckt vorliegt! Jüngere Physiker, wie Prof. Kučera, Felix, Doz. Záviška sind treue Schüler von Koláček, insbesondere auch in ihrer Haltung mir gegenüber, und so habe ich hier nur Prof. Strouhal auf meiner Seite.

Wenn ich darauf denke, wie bitter ich mir den Urlaub erkämpfen musste, welche verschiedenartige Schwierigkeiten ich auch während des Urlaubs überwinden musste, welche Schicksalsschläge mich noch zu derselben Zeit getroffen haben, wie lange es dauerte, bevor ich mich auf die Publizierung der Arbeit ?freuen konnte, so wird mir recht schwer zu Mute! Dazu kommt noch, dass ich das ganze vorige Schuljahr - sehr zu meinem Bedauern - verhindert wurde, die Abhandlung fertigzustellen! Die Gründe davon habe ich Ihnen seinerzeit anzugeben. Und jetzt ist wieder ein halbes Jahr verflossen. Wenn ich noch hinzufüge, dass ich um die Publikation dieser Arbeit wirklich „Alles dreht“, dass davon nicht nur meine ganze Zufriedenheit und meine Rehabilitation vor „ungläubigen“ Bekanten, sondern noch viel mehr abhängt, so glaube ich, dass Sie, hochgeehrter Herr Professor, in Erwägung aller dieser Umstände mir diesen Brief nicht verübeln werden und mir nach Möglichkeit bald die Abhandlung zuzusenden die Güte haben werden! Ihr Hochachtungsvoll Ergebener

Jul. Suchý.

Dopis č. 7: J. Suchý H. A. Lorentzovi 18. 4. 1911

Smíchov 18. 4. 1911.

Hochgeehrter Herr Professor!

Soeben beantwortete ich telegraphisch Ihre Depesche. Sicherheitshalber schreibe ich noch. Die Adresse war richtig, nur fehlte darin das Wort „Smíchov“ (Prage Vorort), was die Folge hatte, dass ich das Telegramm um einige Stunden später erhielt (nach 8 Uhr). Meine Adresse lautet also: Prag-Smíchov/Smíchov bei Prag, Kobrova ul. 12. Oder auch kürzer: Smíchov, No. 1000, da wir in Prag und den Vororten doppelte Hausnummerirung haben, d. h. die Konskriptionsnummer: 1000 z. B. (Katasternummer), und die Orientirungsnummer in der betreffenden Gasse: Kobergasse 12. Die erste Bezeichnungsart ist 
mehr vorbreitet. Dies erlaubte ich mir mitzuteilen, um etwaigen Missverständnissen in der Zukunft vorzubeugen.

Ihren werten Brief vom 29. März habe ich richtig erhalten und freute mich seit dem angegebenen Termin täglich auf die Ankunft der Abhandlung. Hoffentlich ist dieselbe abgegangen, bevor dieser Brief kam. Ich verbliebe in vollkommener Hochachtung Ihr

dankbar Ergebener

Jul. Suchý

Dopis č. 8: J. Suchý H. A. Lorentzovi 22. 4. 1911 (kopie viz obr. 3)

Smíchov 22. 4. 1911.

Hochgeehrter Herr Professor!

Ich bestätige dankend dem Empfang Ihres werten Briefes, der Anmerkungen zu der Abhandlung und des Manuskriptes. Alles ist gestern in Ordnung angekommen. Obwohl ich begreiflicherweise bisjetzt (!) noch nicht die vielen und wertvollen Anmerkungen und Ratschläge durchlesen konnte, so kann ich doch nicht umhin, um nicht schon heute meinen innigsten dank Ihnen, hochgeehrter Herr Professor, für die grosse Mühe und Liebenswürdigkeit auszusprechen! Ich werde mich bemühen, die Arbeit möglichst im Sinne Ihres Ratschläge und Wünsche umzugestalten. Denn ist weiss, das dieselben alle gut gemeint und aus dem so grossen Fond Ihrer Erfahrung geschöpft sind. So bald, als bei meiner Schulbeschäftigung nur möglich, werde ich die Abhandlung zurücksenden. Dann werde ich auch ausführlicher Ihren liebenswürdigen Brief, aus dem ich grosse Freude hatte, beantworten. Heute wollte ich nur den wichtigen Empfang der für mich so wichtigen Sendung bestätigen. Mit besten Empfehlungen auch von meiner Gemahlin, verbliebe ich hochachtungswohl Ihr dankbar Ergebener

Jul. Suchý

Dopis č. 9: J. Suchý H. A. Lorentzovi 11. 6. 1911

Hochgeehrter Herr Professor!

Smíchov 11. VI. 1911.

Gleichzeitig erlaube ich mir Ihnen meine Abhandlung eingeschrieben zu übersenden. Ich bitte, mich gütigst zu entschuldigen, wenn die Arbeit etwas später ankommt, als Sie, Herr Professor, etwa erwartet haben, und als auch ich sehr gewünscht hätte. Aber ich musste die Abhandlung gänzlich umarbeiten, und bei meiner Schulbeschäftigung ging das nicht so rasch vorwärts. Trotzdem wäre die Verzögerung nicht bedeutend gewesen, wenn sich nicht gerade in jenen Wochen ein trauriges Ereignis zugetragen hätte. Im vorigen Monat ist nämlich mein guter Schiegervater gestorben.

Da ich überhaupt unter ziemlich schwierigen Umständen an der Umarbeitung der Abhandlung gearbeitet habe, so weiss ich nicht, ob ich allen Ihren, gewiss sehr gut gemeinten Intentionen gerecht wurde. So bitte ich z. B. die neu hinzugekommenen numerischen Berechnungen (z. B. S. 51., 52.) einer kurzen Prüfung unterziehen zu wollen.

Es wäre nun sehr angenehm, wenn die Abhandlung noch in dem Juli-Heft der Annalen abgedruckt werden könnte. Nur weiss ich nicht, ob dies noch möglich ist. Ich bin Ihnen, hochgeehrter Herr Professor, sehr dankbar dafür, dass Sie es übernommen haben, die Abhandlung an die Redaktion der Annalen selbst zu senden. Schon das allein wird, wie ich hoffe, die Publizirung beschleunigen. Ausser den Gratis-Separatabdrücken möchte 
ich noch 50-100 (je nach dem Preis) bezahlte bestellen. Ich bitte mich deshalb gefälligst benachrichtigen zu wollen, falls Sie, Herr Professor, eine Nachricht erhalten sollten, in welcher Nummer die Abhandlung erscheint, damit ich mich rechtzeitig an den Verleger wenden kann.

Indem ich Ihnen, sehr geehrter Herr Professor, nochmals bestens Danke für die grosse Mühe, die Sie sich mit dem Lesen der Abhandlung gegeben haben und noch geben werden, und für die zahlreichen wertvollen Ratschläge, verbleibe ich, mit besten Empfehlungen auch von meiner Gemahlin,

Ihr hochachtungsvoll Ergebener

Jul. Suchý.

\section{Obrazová př́loha}

\section{ANNALEN DER \\ P H Y S I K. \\ BRGRUNADET UND VORTGRFIHIRT DURCH}

F. A. C. GRRN, L. W. GILBERT, J. C. POgGWNDOREF, G. ч. K. WIEDRMANN, P. IRGDR. VIERTE FOLGF.

BAND 36.

DER QANZBN REIHE 341. BAND

KURATORIUM

M. PLANCK, G. QUUNCKE,

W. C. RÖNTGEN, W. VOIGT, E. WARBURG.

UNTER MITWIRKUNG

DER DEUTSOHEN PHYSIKALISCHEN GESELLSOHAFT

HBRAUSGEGEBEN VON

W. WIEN UND MI. PLANCK.

MIT VIER FIGURENTAFELN.

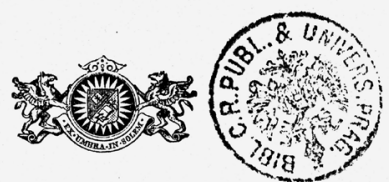

4. Wärmestrahlung und Wämeleitung;

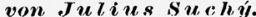

\& 1. Es ist mehrmals die Vermutung ausgesprochen worden, daß der Wärmeübergang, den man als "Leitung" bezeichnet, vielleicht zum Teil daher rührt, daß benachbarte Teile der Körper sich Wärme zustrahlen. Andeutungen in dieser Richtung findet man schon bei Fourier in seinem klassischen Werke; ferner hat H. F. Weber ${ }^{1}$ ) die Ansicht ausgesprochen, daB die Wärmeleitung in durchsichtigen nichtmetallischen Flüssigkeiten durch Atombewegung, also kinetisch, in Metallen dagegen durch Strahlung geschehe. Auch K. Puschl ${ }^{2}$ ) unterscheidet zwei Arten der Wärmeleitung, die aber gleichzeitig stattfinden sollen: die kinetische und die aktinische Wärmebewegung. Eine eigentümliche Theorie der Wärmeleitung rührt von 0 . Wiedeburg ${ }^{3}$ ) her; sie ist eng verknüpft mit der von demselben Forscher aufgestellten Theorie der Thermoelektrizität.

Von der Seite der Wärmestrahlung aus haben R.A.Sampson $\left.{ }^{4}\right)$ und A. Schuster ${ }^{5}$ ) einen AnschluB an die Wärmeleitung gesucht. Der Versuch von J. Boussinesq ${ }^{9}$ ), die Wärmeleitung in festen Körpern nicht kinetisch, sondern als das Produkt der inneren Stralulung aufzufassen, führte wieder zu den Gleichungen von Fournier.

1) H. F. Weber, Wied. Ann. 10. p. 103.1880

2) K. Puschl, Wien. Ber. 103. p. 809, 989. 1894.

3) 0. Wiedeburg, Ann. d. Phys. 1. p. 784. 1900

4) R. A. Sampson, Memoirs of the Royal Astronom. Soc., vol. LI.

5) A. Sehuster, Phil. Mag. (6) 5. p. 243. 1903. Vgl. dazu:

J. Königsberger, Ann. d. Phys. 12. p. 342. 1903.

6) J. Boussinesq, Théorie anal. de la chaleur. Tọme I.

Obr. 1: Titulní list časopisu Annalen der Physik z roku 1911 a první strana publikace J. Suchého uveřejněné v tomto časopise 


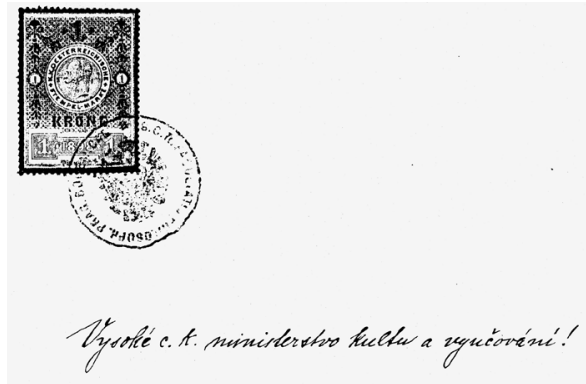

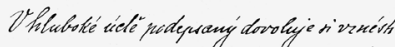

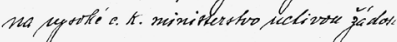

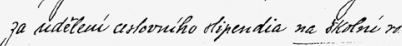

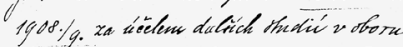

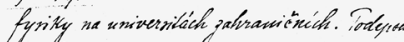

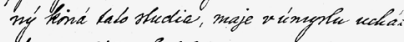
St he pordicy o kabilitaci puo otor fynity na

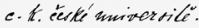

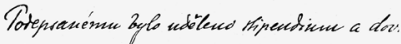

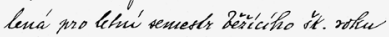

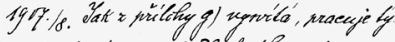

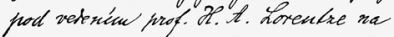

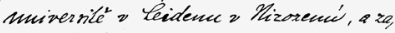

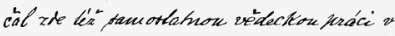
oborw electhonose' theorie. By hodennra'm.

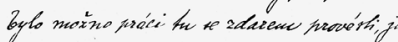

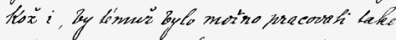
- Caboralóñ prof. Námerlingha Cunesa m univarité v Heidenw, zada' nodepstany

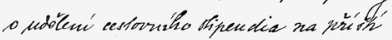

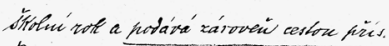

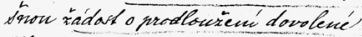

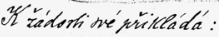

a) nyroénatené maturitué,

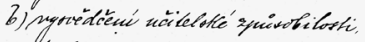

c) clintoru dostiorstié,

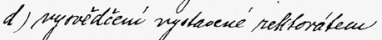

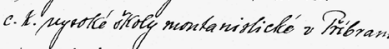

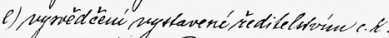

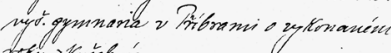
truc z thasebuén

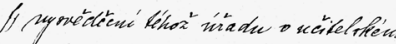

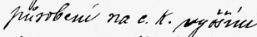

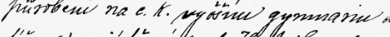

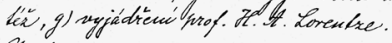

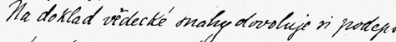
n' moééti neitrecé no mace.

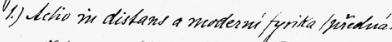

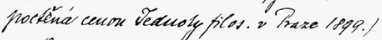

2. Opyroilestrinus (atrestace)

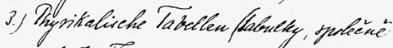

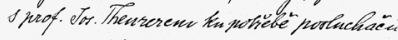

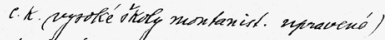

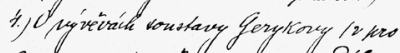

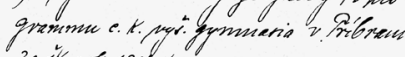
za the pore sgos. 15 .

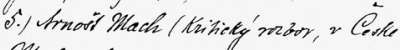
Myrai 1908.)

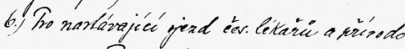

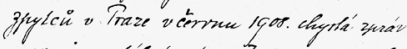

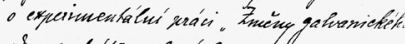

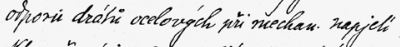

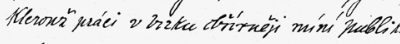
vati.

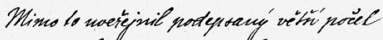

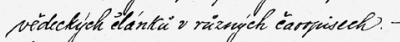

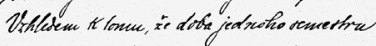

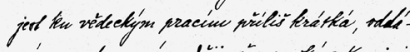

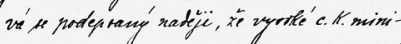

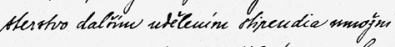

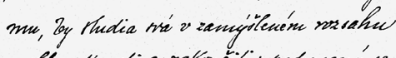

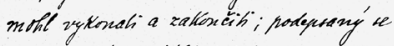

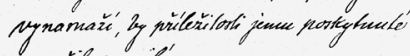

$$
\begin{aligned}
& \text { yperit eo rajlépe } \\
& \text { Leiden 19. Toritna sgos. } \\
& \text { (Vreewitkstraatiq)) }
\end{aligned}
$$

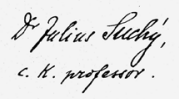

Obr. 2: Rukopisná žádost J. Suchého o cestovní stipendium na školní rok 1908/1909 $\mathrm{k}$ dokončení započaté práce $\mathrm{v}$ Leidenu [Archiv UK] 
Smishoo 22.4 .1911$.

Doshgechnter Hear Professor?

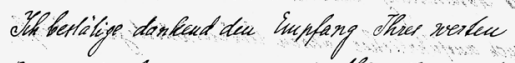

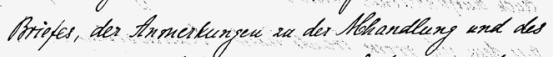

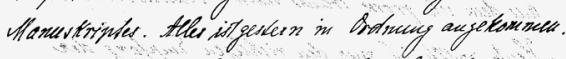

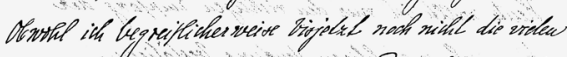

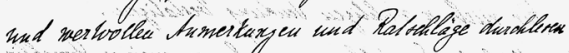

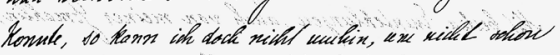

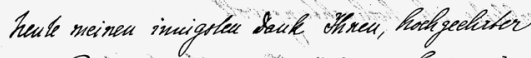

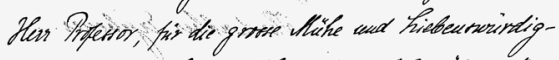

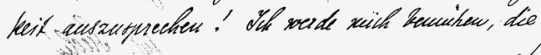

Obr. 3: Rukopis dopisu J. Suchého H. A. Lorentzovi z 22. 4. 1911 [Noord-Hollands Archief, Haarlem, NL]

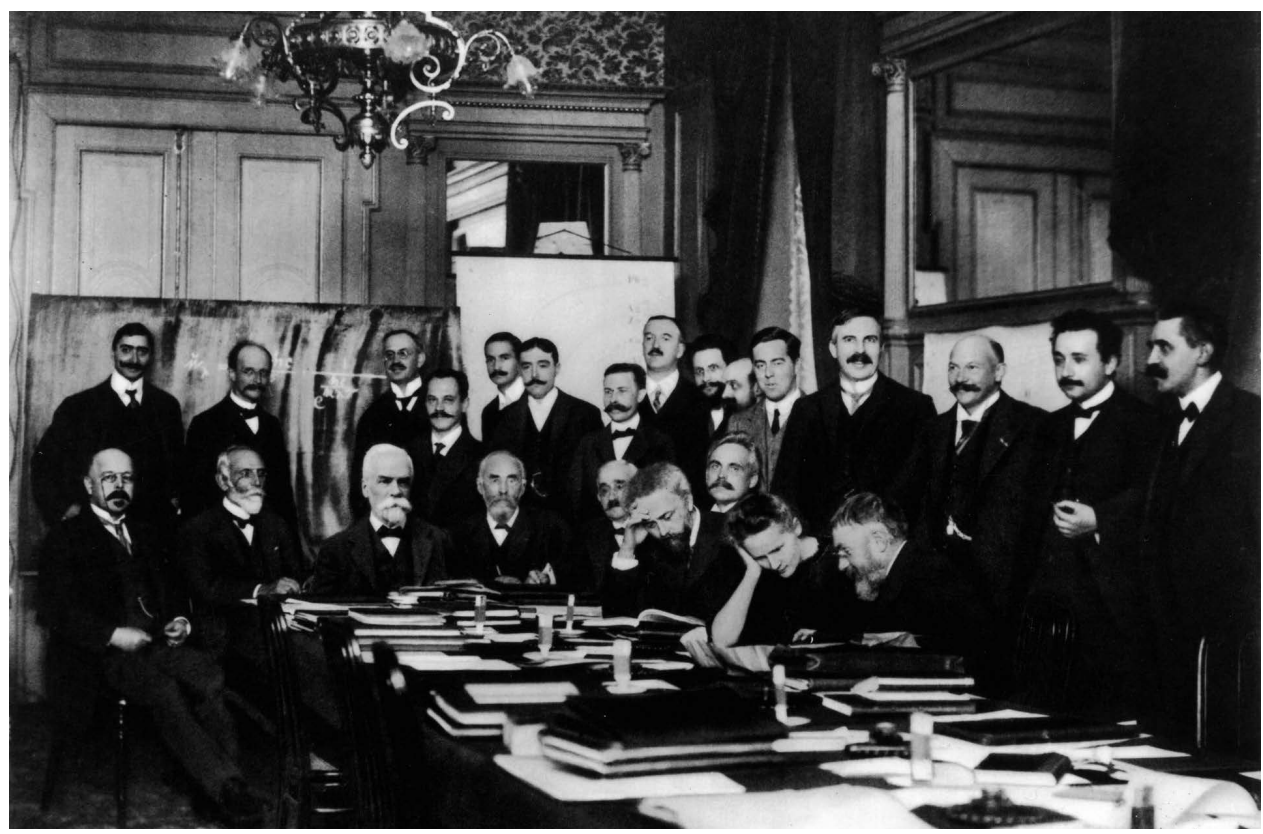

Obr. 4: Fotografie z prvního Solvayského kongresu v Bruselu v roce 1911 (H. A. Lorentz za stolem čtvrtý zleva, A. Einstein stojí druhý zprava, Max Planck stojí druhý zleva) [<https://cosmolearning.org/images/1911-first-solvay-conference-on-physics $>$ ] 


\title{
Die Habilitation Julius Suchýs für theoretische Physik an der Tschechischen Technischen Hochschule in Prag
}

\author{
ZUSAMMENFASSUNG
}

Anlass zu diesem Artikel gab die von J. Ratajová besorgte und in diesem Band abgedruckte Edition. Der Artikel beschreibt den Aufenthalt des tschechischen Physikers Julius Suchý bei Hendrik A. Lorentz an der Universität Leiden und die weiteren Umstände seiner anschließenden Habilitation für theoretische Physik an der Tschechischen Technischen Hochschule in Prag im Jahre 1913.

Julius Suchý wurde 1879 in Kroměřǐž (Kremsier) in Mähren geboren. Nach dem Abitur am dortigen tschechischen Gymnasium (1897) studierte er Mathematik und Physik an der Universität Wien und an der tschechischen Universität Prag (1902 Dr. der Philosophie). Seine Berufslaufbahn begann er im November 1899 als Assistent am Lehrstuhl für höhere Mathematik und Physik an der Bergakademie in Př́ibram. Im September 1905 trat er sein Amt als Mittelschullehrer an der höheren tschechischen Realschule auf der Prager Kleinseite an. Im Frühjahr 1908 erhielt er nach wiederholten Anträgen, die seine Ambitionen begründeten, sich an der Prager tschechischen Universität für Physik habilitieren zu wollen, ein Stipendium des österreichischen Ministeriums für Kultus und Unterricht, das ihn zu H. A. Lorentz an die Universität Leiden führte. Von diesem Studienaufenthalt kehrte er am Ende des Schuljahres 1908/09 zurück. Unter der Leitung von H. A. Lorentz begann er sich mit der Elektronentheorie zu beschäftigen. Die in Leiden begonnene Arbeit über Wärmestrahlung und Wärmeleitung hatte er jedoch nicht zu Ende geführt, so dass für das Habilitationsverfahren an der Prager Universität einem anderen Kandidaten der Vorzug gegeben wurde.

Bei der Fertigstellung seiner in Leiden begonnenen Arbeit stieß J. Suchý bei den Vertretern der theoretischen Physik an den tschechischen Hochschulen indes auf kein Verständnis und keine Unterstützung. So habe sich beispielsweise Professor František Koláček sehr skeptisch über die Elektronentheorie geäußert. Derartige Einstellungen zur Elektronentheorie könnten mit dem Einfluss von Ernst Mach im tschechischen Milieu zusammenhängen.

Mit der Fertigstellung seiner Arbeit Wärmestrahlung und Wärmeleitung und ihrer Veröffentlichung in den Annalen der Physik in der zweiten Jahreshälfte 1911 war H. A. Lorentz aus der Ferne J. Suchý behilflich. Im Anschluss an die Veröffentlichung stellte J. Suchý an der Tschechischen Technischen Hochschule in Prag am 28. November 1911 einen Antrag auf Habilitation für theoretische Physik und legte als Habilschrift die erwähnte Arbeit vor. Das Habilitationsverfahren zog sich freilich in die Länge. Seitens des Referenten der Habilkommission, des Professors der Physik Václav Felix, wurden gegenüber der Arbeit gewisse Vorbehalte vorgebracht, die offenbar mit dem Standpunkt von Prof. F. Koláček im Einklang standen. In der entstandenen Situation wandte sich J. Suchý an Albert Einstein, Professor für theoretische Physik an der Deutschen Universität Prag, mit dem Ersuchen um ein Gutachten seiner Habilarbeit. Wie J. Ratajová belegen kann, war das Gutachten A. Einsteins vom 15. Juli 1912 voller Lob. Für den erfolgreichen Abschluss des Habilitationsverfahrens J. Suchýs an der Tschechischen Technischen Hochschule spielte es die entscheidende Rolle. Die Habilitation J. Suchýs für theoretische Physik wurde vom österreichischen Ministerium für Kultus und Unterricht am 28. August 1913 bestätigt.

Im Jahre 1919, nach Gründung des selbstständigen tschechoslowakischen Staates, wurde J. Suchý mit der Ausarbeitung eines Entwurfs des Staatlichen Radiologischen Instituts RČS beauftragt; nach Gründung dieses Instituts ernannte man ihn am 5. Dezember 1919 zu seinem ersten Vorsteher. Kurz darauf wurde er zum ordentlichen Professor an dem neu eingerichteten zweiten Lehrstuhl für Physik an der Tschechischen Technischen Hochschule in Prag berufen. Die vielversprechend sich gestaltende Berufslaufbahn J. Suchýs fand am 19. August 1920 durch einen tragischen Verkehrsunfall ein jähes Ende.

Die Schwierigkeiten, auf die J. Suchý nach seiner Rückkehr von seinem Studienaufenthalt bei H. A. Lorentz und bei der Fertigstellung seiner Habilarbeit stieß, werden von seinen Briefen an H. A. Lorentz beleuchtet, die in Abschrift des deutschen Originals diesem Artikel beiliegen. Die Originalbriefe befinden sich im schriftlichen Nachlass von H. A. Lorentz im Noord-Hollands Archief in Haarlem (Niederlande).

\section{Emilie Těšinská}

